\begin{tabular}{c|c|c|} 
Mansoura University & Faculty of Engineering \\
Mansoura Engineering Journal & Q
\end{tabular}

\title{
A comparative study on corrosion behavior of ceramic coatings via plasma spray process in $3.5 \% \mathrm{NaCl}$ solution

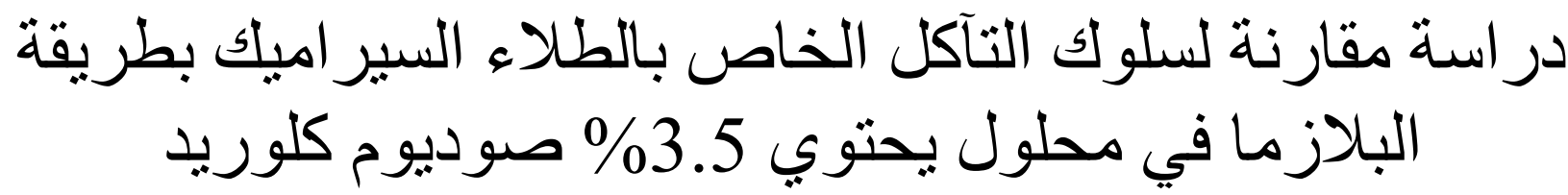

\section{Saber}

KEYWORDS:
Plasma coating; coarse
grain; fine grain;
coating direction;
corrosion

Abstract- In the plasma spray process, material flows through a plasma arc and the molten particles are projected through an inert gas stream with high velocity on AISI 304L stainless steel sheet to give a coating with some degree of metallurgical bonding. This study discusses the effectiveness of particle size, type of coating and direction on the corrosion of ceramic coating in $3.5 \% \mathrm{NaCl}$ solution. Two approaches were used for preparing coated specimens. The first modification proposed to use coarse grain sized powder in spraying as the first layer followed by the fine one. The second trial assumes to change the coating direction of the top layer to be traversing the lower layer. WC-12\% $\mathrm{Co} / \mathrm{Al}_{2} \mathrm{O}_{3}$ coatings were deposited on AISI 304L stainless steel by means of a plasma spray process by different deposition techniques. For comparative purposes, a set of ceramics coatings via plasma spray process was employed on a substrate with $\mathrm{Al}_{2} \mathrm{O}_{3}$, and $\mathrm{WC}-12 \%$ Co. Potentiodynamic polarization measurements were carried out to determine the corrosion behavior of the plasma-sprayed-coatings in $3.5 \% \mathrm{NaCl}$. The results showed that the corrosion resistance depends strongly

Received: 24 December, 2017 - accepted: 18 March, 2018

D. Saber;Materials Engineering Dept., Faculty of Engineering, Zagazig University, Zagazig, Egypt, Email: daliasaber13@yahoo.com, Tel: +2-01063970239; Fax: +2-055-2304987 on the type of coating and on its direction of coating. The grain type combination showed a great influence on the corrosion behavior of the plasma coatings, the coarse $\mathrm{WC}-12 \%$ Co covered by fine $\mathrm{Al}_{2} \mathrm{O}_{3}$ showed a much better corrosion resistance than the fine $\mathrm{WC}-12 \%$ Co covered by coarse $\mathrm{Al}_{2} \mathrm{O}_{3}$. The parallel layers of coating specimen has the best corrosion resistance between the coated specimens with lowest corrosion rate $0.425 \mathrm{~mm} / \mathrm{year}$.

\section{INTRODUCTION}

HE plasma spraying coating can enhance the

$\neg$ contact fatigue resistance, wear and corrosion resistance in metal components as rollers in paper manufacturing, shafts and screws in petrochemical processes, and transmission shafts in construction machinery and cars. Moreover, the plasma spraying technology can be applied to a wide range of materials, such as ceramics, pure metals or alloys, and polymeric materials $[1,2]$. Corrosion-resistant coatings produced by plasma spraying have exhibited good benefits in certain conditions. It is well known that $\mathrm{Al}_{2} \mathrm{O}_{3}, \mathrm{Al}_{2} \mathrm{O}_{3}+\mathrm{TiO}_{2}, \mathrm{Cr}_{2} \mathrm{C}_{3}+\mathrm{NiCr}, \mathrm{NiAl}$, $\mathrm{NiCrAl}, \mathrm{ZrO}_{2}$ and $\mathrm{WC}-\mathrm{Co}$ powders which are used in plasma 
coatings are resistant to specific corrosion media which are widely engaged in industry. The corrosion behavior of plasma sprayed coatings depends on the following elements: corrosive media, substrate and their surface state, environmental temperature, composition, structure, porosity, thickness, adhesive strength and other properties of the coatings [3,4]. The pitting corrosion caused by the connected pores and micro-cracks in the coating may decrease the corrosion resistance of the plasma sprayed coating. Many means have been put forward to solve the pitting corrosion problem in ceramic coating such as sealing treatment, laser remolding, and increasing the thickness of the coating by spraying more than one ceramic layer over each other. [5]. Increasing thickness by doubling layer of ceramic coating increases toughness and is one of the best ways to decrease the connected pores in the coating and accurate covering of the substrate by the coating due to the high thermal stress induced in the process of spraying, and this always depends on the deposition processes and techniques of the ceramics spraying. Aluminum oxide $\left(\mathrm{Al}_{2} \mathrm{O}_{3}\right)$ has a very high melting point and it is a good coating because of a very hard bond layer. Tungsten carbide-cobalt (WC-Co) based materials used extensively in industry in their sintered as well as thermally sprayed forms for applications requiring abrasion, sliding, and erosion corrosion resistance. The hard WC particles from the major wear-resistant constituent of these materials, while the cobalt binder provides toughness and cohesion. Properties such as hardness, wear resistance and strength influenced primarily by the WC grain size and volume fraction and with thermally sprayed coatings also by varying the porosity and the carbide and binder (Co) phase composition [6,7]. The anisotropic microstructure of thermally sprayed WC- $12 \%$ Co coatings, changes when it's sprayed in a direction parallel to the substrate and when sprayed in a vertical direction to the substrate, also the grain types whether it's fine or coarse grains all of these conditions influence the coating properties and performance against corrosion of the surface. The aim of this work is to compare the corrosion resistance of AISI 304L stainless steel, coated with $\mathrm{WC}-12 \% \mathrm{Co} / \mathrm{Al}_{2} \mathrm{O}_{3}$ using a plasma spray process by different deposition techniques and parameters and AISI 304L stainless steel coated with $\mathrm{Al}_{2} \mathrm{O}_{3}$, and $\mathrm{WC}-12 \%$ Co.

TABLE 1

\begin{tabular}{|c|c|c|c|c|}
\hline \multicolumn{5}{|c|}{ POWDER SPECIFICATIONS } \\
\hline Powders & $\begin{array}{l}\text { Density } \\
\text { g/cm }\end{array}$ & $\begin{array}{c}\text { Melting } \\
\text { Temperature } \\
{ }^{\circ} \mathbf{C}\end{array}$ & $\begin{array}{c}\text { Grain Size } \\
\qquad \mu \mathrm{m}\end{array}$ & $\begin{array}{c}\text { Coating } \\
\text { Hardne } \\
\text { ss } \\
\text { Kp/mm² } \\
\text { HV0.1 }\end{array}$ \\
\hline $\begin{array}{c}\text { Aluminum } \\
\text { oxide Powder }\end{array}$ & 4.05 & $1788-2000$ & $\begin{array}{c}\text { Fine }=5-25 \\
\text { Coarse }= \\
12-40\end{array}$ & $\begin{array}{l}\mathrm{HV} \\
1000\end{array}$ \\
\hline $\begin{array}{c}\text { Tungsten } \\
\text { Carbide(WC)- } \\
\text { Cobalt(Co) } \\
\text { WC- } 12 \% \mathrm{Co}\end{array}$ & 13.75 & $\begin{array}{c}\text { Co is melting at } \\
1459 \\
\text { WC is melting } \\
\text { at } 2777\end{array}$ & $-45+5$ & $\begin{array}{c}\mathrm{HV} \\
2000\end{array}$ \\
\hline
\end{tabular}

\section{EXPERIMENTAL DETAILS}

The substrate used in this study was AISI 304L stainless steel, with the dimensions of $25 \times 20 \times 2 \mathrm{~mm}$. These specimens were grit-blasted with grade 45 alumina grit to improve the adherence of the coating and to provide a surface roughness in the range of 2.3 to $3.6 \mu \mathrm{m}$. After that the specimens were cleaned in specially developed hot vapor washing tanks followed by Trichlorethane and Trichlortrifluorethane solutions as a finishing cleaning operation. The ceramic coatings were carried out via atmospheric plasma spray (APS) equipment with a F4-MB torch. Table.1 shows the powder specifications and Table.2 lists the different deposition techniques used for each sample. Coating structure was examined using scan electron microscope.

Electrochemical test was conducted in $3.5 \% \mathrm{NaCl}$ solution prepared prior to each test using distilled water. All electrochemical experiments were conducted with a Gamry PCI300/4 Potentiostat / Galvanostat/Zra analyzer. It was connected to a PC. The Echem Analyst software (version 5.21) was used for all electrochemical data analysis. A threeelectrode cell composed of a specimen as a working electrode, platinum. Counter electrode, and saturated calomel electrode (SCE) as a reference electrode used for the tests. Tafel polarization tests were carried out using a scan rate of 0.5 $\mathrm{mV} / \mathrm{min}$ at room temperature.

TABLE 2.

THE DIFFERENT DEPOSITIONS TECHNIQUES ON EACH SAMPLE.

\begin{tabular}{|c|c|c|}
\hline Coating Cases & $\begin{array}{l}\text { Specimens } \\
\text { code }\end{array}$ & Depositions Techniques \\
\hline $\begin{array}{c}\mathrm{WC} \perp \mathrm{WF} \\
\text { Perpendicular } \\
\text { coating (WC-12\% } \\
\text { Co) }\end{array}$ & W1 & $\begin{array}{l}\text { Coarse grain sized powder of } \\
\text { tungsten carbide followed the fine } \\
\text { one of tungsten carbide normal to } \\
\text { be traverse the lower layer }\end{array}$ \\
\hline $\begin{array}{c}\mathrm{WC}=\mathrm{WF} \\
\text { parallel coating } \\
(\mathrm{WC}-12 \% \mathrm{Co})\end{array}$ & W2 & $\begin{array}{l}\text { Coarse grain sized powder of } \\
\text { tungsten carbide followed the fine } \\
\text { one of tungsten carbide to be the } \\
\text { same coating direction }\end{array}$ \\
\hline $\begin{array}{c}\mathrm{AlC} \perp \mathrm{AlF} \\
\text { Perpendicular } \\
\text { coating }\left(\mathrm{Al}_{2} \mathrm{O}_{3}\right)\end{array}$ & A1 & $\begin{array}{l}\text { Coarse grain sized powder of } \\
\text { aluminum oxide followed the fine } \\
\text { one of aluminum oxide normal to } \\
\text { be traverse the lower layer }\end{array}$ \\
\hline $\begin{array}{c}\mathrm{AlC}=\mathrm{AlF} \\
\text { parallel coating } \\
\left(\mathrm{Al}_{2} \mathrm{O}_{3}\right)\end{array}$ & A2 & $\begin{array}{l}\text { Coarse grain sized powder of } \\
\text { aluminum oxide followed the fine } \\
\text { one of aluminum oxide to be the } \\
\text { same coating direction }\end{array}$ \\
\hline $\begin{array}{c}\mathrm{WC}=\mathrm{AlF} \\
\text { parallel coating } \\
\left(\mathrm{WC}-12 \% \mathrm{Co} / \mathrm{Al}_{2} \mathrm{O}_{3}\right)\end{array}$ & WA1 & $\begin{array}{l}\text { Coarse grain sized powder of } \\
\text { tungsten carbide followed the fine } \\
\text { one of aluminum oxide to be the } \\
\text { same coating direction }\end{array}$ \\
\hline $\begin{array}{c}\mathrm{WF}=\mathrm{AlC} \\
\text { parallel coating } \\
\left(\mathrm{WC}-12 \% \mathrm{Co} / \mathrm{Al}_{2} \mathrm{O}_{3}\right)\end{array}$ & WA2 & $\begin{array}{l}\text { Fine grain sized powder of } \\
\text { tungsten carbide followed the } \\
\text { coarse one of aluminum oxide to be } \\
\text { the same coating direction }\end{array}$ \\
\hline $\begin{array}{c}\mathrm{WC} \perp \mathrm{AlF} \\
\text { Perpendicular } \\
\text { coating(WC-12\% } \\
\left.\mathrm{Co} / \mathrm{Al}_{2} \mathrm{O}_{3}\right)\end{array}$ & WA3 & $\begin{array}{l}\text { Coarse grain sized powder of } \\
\text { tungsten carbide followed the fine } \\
\text { one of aluminum oxide normal to } \\
\text { be traverse the lower layer }\end{array}$ \\
\hline $\begin{array}{c}\mathrm{WF} \perp \mathrm{AlC} \\
\text { Perpendicular } \\
\text { coating(WC-12\% } \\
\left.\mathrm{Co} / \mathrm{Al}_{2} \mathrm{O}_{3}\right)\end{array}$ & WA4 & $\begin{array}{l}\text { Fine grain sized powder of } \\
\text { tungsten carbide followed the } \\
\text { coarse one of aluminum oxide to } \\
\text { be traverse the lower layer }\end{array}$ \\
\hline
\end{tabular}




\section{RESULTS AND DISCUSSION}

\section{A. Microstructures}

The SEM micrographs of plasma-sprayed-coatings (PSC) are given in Fig.1. It is shown that (PSC) may exhibit porosity, oxides, un-melted particles and inclusions. The ceramic coatings of perpendicular spray direction denoted by (W1 for WC-12\% Co, A1 for $\mathrm{Al}_{2} \mathrm{O}_{3}$ ) shows more porous structure compared to the parallel coatings denoted by (W2 for WC-12\% Co, $\mathrm{A} 2$ for $\left.\mathrm{Al}_{2} \mathrm{O}_{3}\right)$ as shown in Fig.1(a-d). For instance, the $\mathrm{WC}-12 \%$ Co coating exhibits high porosity with large pore sizes and relatively wide distribution. For $\mathrm{Al}_{2} \mathrm{O}_{3}$ coating, the defects were mainly in the form of micro pores, and no visible micro cracks were found in it as illustrated in Fig.1 (c, d). The pores are caused by the splashing of particles on impact with deposited material [8]. It may be due to voids resulting from the poor deformation of partially melted particles. These pores can have different sizes and exceedingly intricate shapes [9]. The presence of pores, cracks, and localized compositional variations could degrade corrosion resistance [10].
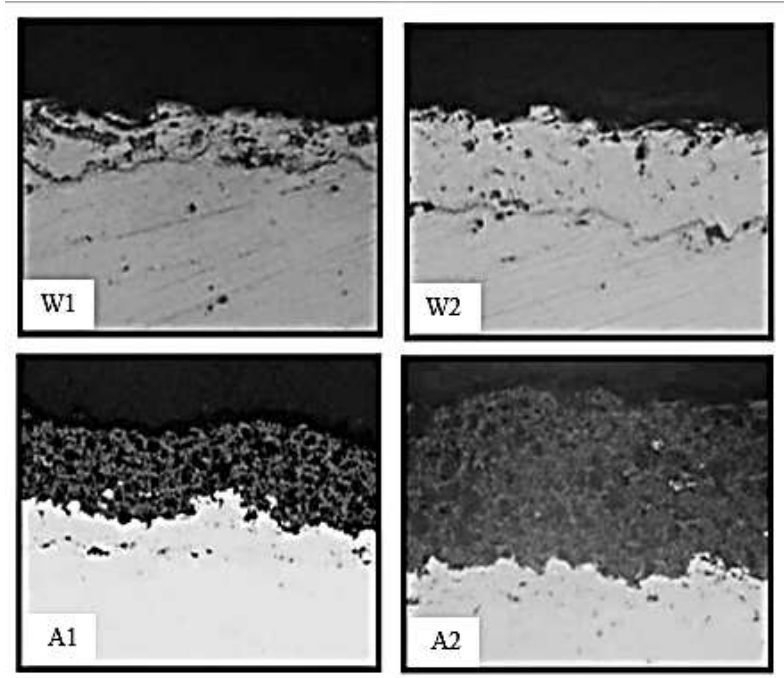

Fig. 1 Microstructure of coated specimens W1, W2 coated by WC-12\% $\mathrm{Co}$ and $\mathrm{A} 1, \mathrm{~A} 2$ Coated by $\mathrm{A} 12 \mathrm{O} 3$

Figure. 2 indicate less separation if the coarse grains are the lining and those fine are the outermost layer. Because of the fine grains filled the voids in the coarse grain. As shown in Fig.2 (a, c) the parallel coating was more homogeneous than the perpendicular one Fig.2 (b, d). The homogeneous structure improved the corrosion properties of the coated specimens $[11,12]$

\section{B. Corrosion test:}

The corrosion results were summarized in table (3). As shown in table (3) the corrosion potentials of the perpendicular coated samples show more negative values compared to the parallel-coated samples, which means that the perpendicular deposits had active surfaces and higher thermodynamic tendency to corrode. The corrosion potential of the specimen


Fig.2 Microstructure of coated specimens with WC-12\% Co/Al2O3

W1 was more negative as compared to the specimen W2. As well as the corrosion potential of the specimen A1 was more negative than the specimen A2. The parallel coated specimen with $\mathrm{WC}-12 \% \mathrm{Co} / \mathrm{Al}_{2} \mathrm{O}_{3}$, WA1 verified the most noble corrosion potential $(-0.362 \mathrm{~V})$. As it is evident from the table (3) that the parallel coatings have shown more corrosion resistance as compared to perpendicular coatings. In addition, the coated specimens with $\mathrm{Al}_{2} \mathrm{O}_{3}$ (A1, A2) were more corrosion resistance than the coated specimens with WC$12 \%$ Co $(\mathrm{W} 1, \mathrm{~W} 2)$.

TABLE 3.

ELECTROCHEMICAL PARAMETERS CALCULATED FROM THE POLARIZATION

\begin{tabular}{c||c||c||c}
\multicolumn{1}{c||}{ Coating Cases } & $\begin{array}{c}\text { Specimens } \\
\text { code }\end{array}$ & $\begin{array}{c}\text { E } \\
\text { Corrosion } \\
(\mathbf{V})\end{array}$ & $\begin{array}{c}\text { Corrosion } \\
\text { rate(mm/year) }\end{array}$ \\
\hline $\mathrm{WC} \perp \mathrm{WF}$ & $\mathrm{W} 1$ & -0.720 & 2.393 \\
\hline $\mathrm{WC}=\mathrm{WF}$ & $\mathrm{W} 2$ & -0.688 & 0.981 \\
\hline $\mathrm{AlC} \perp \mathrm{AlF}$ & $\mathrm{A} 1$ & -0.436 & 1.156 \\
\hline $\mathrm{AlC}=\mathrm{AlF}$ & $\mathrm{A} 2$ & -0.369 & 0.724 \\
\hline $\mathrm{WC}=\mathrm{AlF}$ & $\mathrm{WA} 1$ & -0.362 & 0.425 \\
\hline $\mathrm{WF}=\mathrm{AlC}$ & $\mathrm{WA} 2$ & -0.462 & 0.615 \\
\hline $\mathrm{WC} \perp \mathrm{AlF}$ & $\mathrm{WA} 3$ & -0.538 & 3.197 \\
\hline $\mathrm{WF} \perp \mathrm{AlC}$ & $\mathrm{WA} 4$ & -0.406 & 7.124
\end{tabular}

On the other hand, the parallel coated specimens with $\mathrm{WC}$ $12 \% \mathrm{Co} / \mathrm{Al}_{2} \mathrm{O}_{3}$, (WA1, WA2) have shown higher corrosion resistance as compared to other specimens. The corrosion rate of the specimens with parallel coatings, WA1 and WA2 was 0.425 and $0.615 \mathrm{~mm} /$ year respectively.

Whereas the corrosion rate is maximum in case of the specimen WA4. The corrosion rate of this specimen recorded $7.124 \mathrm{~mm} /$ year. 
Figure 3, 4 shows the potentiodynamic polarization curves of the plasma-sprayed coatings by using perpendicular and parallel deposition techniques in $3.5 \% \mathrm{NaCl}$. The corrosion behavior shown in Figs.3 \& 4 confirmed that the coating process greatly influenced the coating performance. Figure 3.a shows that the corrosion potential of specimen W2 was shifted toward the noble direction compared with specimen W1. In addition, the passive range for the specimen W2 was larger than W1. Similar trend was also observed for the specimens A1, A2 in Fig 3.b. As shown in Fig 4.as the specimen WA2 had greater anodic dissolution than the specimen WA1 and its polarization curve shifted to the left, which confirm that WA1 showed better corrosion resistance than the WA2. In Fig. 4.b. the specimen WA4 showed greater anodic dissolution compared with WA3 which means that the specimen WA3 is better corrosion resistant than the specimen WA4.

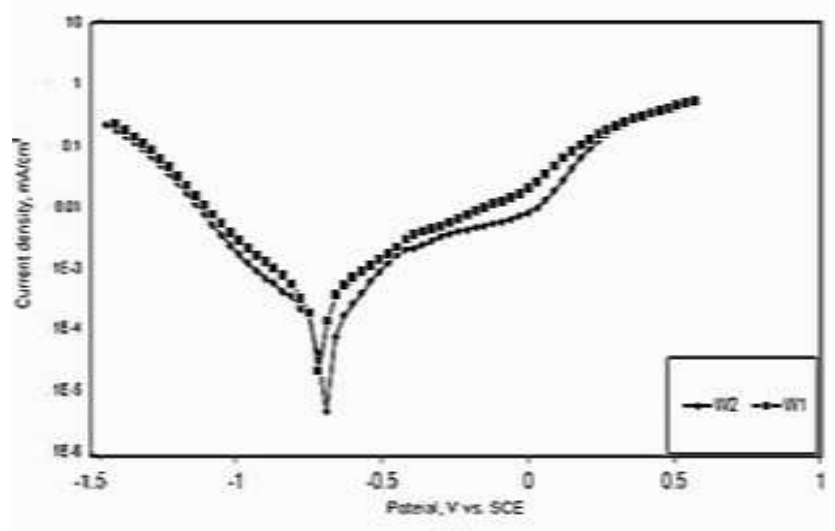

(a)

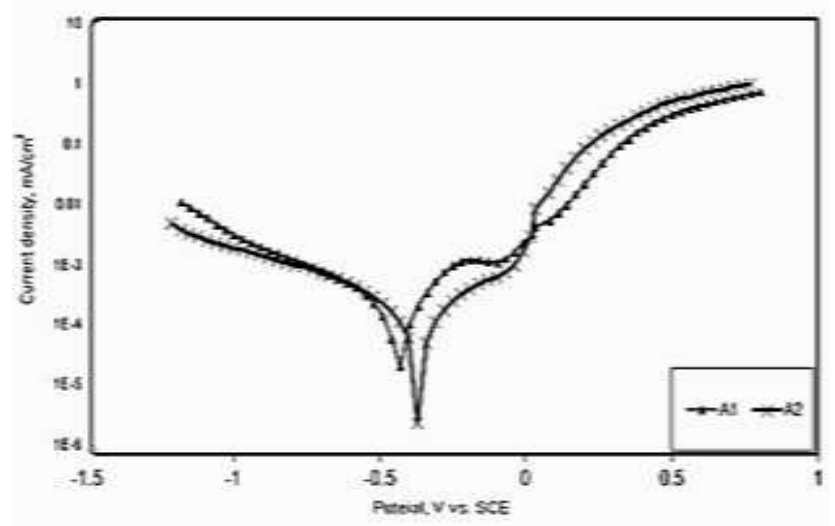

Fig.3 Polarization curves of coated specimens (a) Specimens coated by WC- $12 \%$ Co and (b) Specimens Coated by $\mathrm{Al} 2 \mathrm{O} 3$

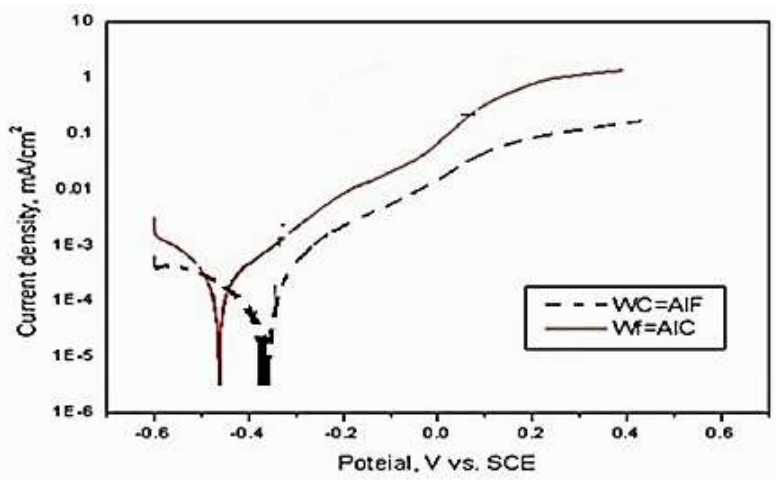

(a)

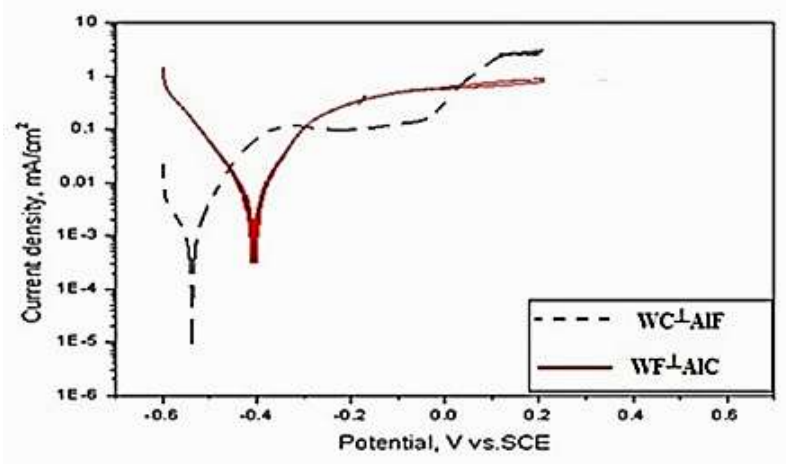

(b)

Fig.4 Polarization curves of coated specimens with WC-12\% $\mathrm{Co} / \mathrm{Al} 2 \mathrm{O} 3$

The grain size and its order as well as the direction and the type of coating have prevalent effects on the corrosion resistant property of the coated specimens. As a general observation, the results confirmed that the parallel deposition technique exhibited a markedly better corrosion resistant ability than the perpendicular deposition technique by virtue of more noble corrosion potential. The parallel coating deposition technique's passive layer was strong and provided more corrosion resistance and protection than that of the perpendicular coating deposition technique. The improvement in corrosion resistance of parallel coatings may be attributed to the chemical stability of the coating layer, which acts as barriers for the corrosion process by reducing the holes and gaps on the surface and consequently preventing the corrosive pits from growing up $[13,14]$. Another observation, the grain type combination also showed a great influence on the corrosion behavior of the plasma coatings, the coarse grain covered by fine grain (W2, A2, WA1, WA3) showed a much better corrosion resistance than the fine grain covered by coarse grain (WA2, WA4b). The reason is that coarse grains have much more microcracks and pores than the fine grains. So when this layer combination of plasma coat was made the fine grain made a strong barrier and cover for the microcracks and pores in the coarse grains. This due to better strong passive layer which was a strong barrier for the electrolyte in the cell used in the corrosion test $(\mathrm{NaCl})$ to pass to the coarse 
grains. So this combination of grains decreased the rate of uniform corrosion and showed a better corrosion behavior than the other combination [15].

\section{CONCLUSION}

The Corrosion behavior of Plasma WC-12\% $\mathrm{Co} / \mathrm{Al}_{2} \mathrm{O}_{3}$ Coatings on AISI 304L stainless steel surface has been studied related to the deposition parameters, Grain types (fine and coarse grains). For comparative purposes, a set of ceramics coatings via plasma spray process was employed on a substrate with $\mathrm{Al}_{2} \mathrm{O}_{3}$, and $\mathrm{WC}-12 \%$ Co. This work displays the economic view of coating process where the expensive cost of this process can be reduced through using the bilayer of coarse grain powder followed by fine grain powder for bilayer coating powder. This lead to decrease the coating thickness as well as the amount of expensive fine grain sized powders. It can be concluded that the parallel layers of plasma coating deposition technique had a better corrosion behavior and resistance than the perpendicular plasma coatings. The parallel layers of coating specimen $\mathrm{WC}=\mathrm{AlF}$ (WA1) has the best corrosion resistance between the coated specimens with lowest corrosion rate $0.425 \mathrm{~mm} /$ year. The grain type combination also showed a great influence on the corrosion behavior of the plasma coatings, the coarse $\mathrm{WC}-12 \% \mathrm{Co}$ covered by fine $\mathrm{Al}_{2} \mathrm{O}_{3}$ showed a much better corrosion resistance than the fine $\mathrm{WC}-12 \%$ Co covered by coarse $\mathrm{Al}_{2} \mathrm{O}_{3}$.

\section{REFERENCES}

[1.] R.Musalek, O. Kovarik, T. Skiba, P. Hausild, M. Karlik. Fatigue properties of $\mathrm{Fe}-\mathrm{Al}$ intermetallic coatings prepared by plasma spraying. Intermetallic 2010; 18:1415-18.

[2.] A. Cattini, D. Bellucci, A. Sola, L. Pawłowski, V. Cannillo. Suspension plasma spraying of optimized functionally graded coatings of bioactive glass/hydroxyapatite. Surface \& Coatings Technology 2013; 236:11826.

[3.] M. Yazıc, O. Çomak, T. Yetimc, A.F. Yetimd, A. Çelik. The effect of plasma nitriding temperature on the electrochemical and semiconducting properties of thin passive films formed on $316 \mathrm{~L}$ stainless Steel implant material in SBF solution" Surface \& Coatings Technology.2015; 261:181-8.

[4.] E. Celik, I. Ozdemir, E. Avci and Y. Tsunekaw. Corrosion behavior of plasma sprayed coatings. Surface and Coatings Technology 2005; 193: 297-302.

[5.] D. Yan, J. He, X. Li, Y. Dong, Y. Liu, and H. Lui. The corrosion behavior of plasma-sprayed Ni/Al- $\mathrm{Al}_{2} \mathrm{O}_{3}$ and $\mathrm{Ni} / \mathrm{Al}-\mathrm{Al}_{2} \mathrm{O}_{3}+13 \mathrm{wt} \% \mathrm{TiO}_{2}$ graded ceramic coatings in $5 \% \mathrm{HCl}$ solution. Surface and Coatings Technology 2003; 176: 30-6.

[6.] H.L. de Villiers Lovelock. Powder/processing/structure relationships in WC-Co thermal spray coatings: a review of the published literature. Thermal Spray Technology 1998; 7: 357-73.

[7.] S.SATHiSH AND M.GeETHA. COMPARATIVE STUDY ON CORROSION BEHAVIOR OF PLASMA SPRAYED $\mathrm{AL}_{2} \mathrm{O}_{3}, \mathrm{ZRO}_{2}, \mathrm{AL}_{2} \mathrm{O}_{3} / \mathrm{ZRO}_{2}$ AND $\mathrm{ZRO}_{2} / \mathrm{AL}_{2} \mathrm{O}_{3}$ COATINGS"TRANSACTIONS OF NONFERROUS METALS SOCIETY OF CHINA 2016; 26,:1336-1344.

[8.] G. Bolelli, L. Lusvarghi, M. Barletta. Heat treatment effects on the corrosion resistance of some Hv of-sprayed metal alloy coatings" Surface \& Coatings Technology 2008; 202: 4839-7.

[9.] P. Siitonen, S.L. Chen, K. Niemi, P. Vuoristo. Electrochemical method for evaluating the corrosion resistance and porosity of thermal sprayed coatings. thermal spray: International Advances in Coatings Technology, C.C. Berndt, Ed., May 25 - June 5, 1992 (Orlando, FL), ASM International, 1992, 853-8.

[10.] R. Hofman, M.P.W. Vreijling, G.M. Ferrari, J.H.W. De Wit. Electrochemical methods for characterization of thermal spray corrosion resistant stainless steel coatings. Electrochemical Methods in Corrosion Research Vi, Pts 1 and 2, P.L. Bonora and F. Deflorian, Eds., Transtec Publications Ltd, 1998, 641- 53.

[11.] Yaran Niu, Xuebin Zheng, Xuanyong Liu, Heng Ji, Chuanxian Ding. Influence of powder size on characteristics of air plasma sprayed silicon coatings. Ceramics International 2012; 38 5897-5.

[12.] J.M. Shockley, S. Descartes, P. Voc, E. Irissou, and R.R. Chromik. The influence of $\mathrm{Al}_{2} \mathrm{O}_{3}$ particle morphology on the coating formation and dry sliding wear behavior of cold sprayed $\mathrm{Al}-\mathrm{Al}_{2} \mathrm{O}_{3}$ composites. Surface \& Coatings Technology 2015; 270: 324-3.

[13.] M Parida, S.P.Nanda and S.C.Mishra Sea water corrosion behavior of plasma sprayed abradable coatings" IOP Conf. Series: Materials Science and Engineering. 2017;178,012018

[14.] Morks Magdi, Fahim Narges, Kobayshi. Microstructural, corrosion behavior and microhardness of plasma sprayed W-Ni composite coatings Transactions of JWRI 2007; 36: 45-50.

[15.] Chun-Cheng Chen and Shinn-Jyh Ding. Effect of Heat Treatment on Characteristics of Plasma Sprayed Hydroxyapatite Coatings" Materials Transactions 2006; 47: 935 - 40. 